\title{
Exploring the relationship between collaboration and farmers' satisfaction at work
}

\author{
Explorando la relación entre colaboración y Satisfacción \\ de los agricultores en el trabajo
}

\author{
Sara Arancibia ${ }^{1}$, Daniel May2* and Gonzalo Moya ${ }^{3}$
}

\begin{abstract}
The concept of sustainable development involves three main dimensions: economic development, environmental sustainability and social sustainability. Some researchers argue that the first two dimensions cannot be achieved without ensuring social sustainability. In spite of this, little attention has been paid to this side of sustainable development. Recent research suggests that a way to achieve social sustainability is by means of collaboration, because it improves social conditions, allowing farmers to increase satisfaction at work. Satisfaction at work, in turn, can motivate farmers to adopt environmental practices. In this context, collaboration is seen as a social activity. The aim of this article is to extend this research and to investigate whether collaboration seen as an economic activity may also influence farmers' satisfaction at work. The material and methods adopted for this purpose correspond to primary data obtained from a questionnaire and processed by means of the Partial Least Squares-Structural Equation Methodology. The results revealed that farmers' participation in collaborative alliances helps them to achieve economic targets such as reducing costs and obtaining higher prices for their production. This in turn positively affects satisfaction at work in terms of farming life and enjoyment. It is concluded, therefore, that collaboration and farmers' satisfaction at work not only has to be linked to a sociological dimension but also to an economic one. These dimensions complement each other and offer new possible strategies for policymakers.
\end{abstract}

Key words: sustainable development, social sustainability, collaboration, satisfaction at work.

\section{RESUMEN}

El concepto de desarrollo sostenible incluye tres dimensiones principales: desarrollo económico, sostenibilidad del medio ambiente y sostenibilidad social. Algunos investigadores argumentan que las dos primeras dimensiones no pueden ser logradas sin que se asegure la sostenibilidad social. A pesar de este argumento, poca atención se le ha dado a esta dimensión del desarrollo sostenible. Investigaciones recientes sugieren que una manera de lograr sostenibilidad social es mediante la colaboración porque esta mejora las condiciones sociales y permite que los agricultores logren mayor satisfacción en el trabajo. A su vez, la satisfacción en el trabajo puede motivar a los agricultores a adoptar prácticas medioambientales. En este contexto la colaboración es vista como una actividad social. El objetivo de este artículo es extender esta línea de investigación y estudiar si la colaboración es entendida como una actividad económica y puede también influenciar en la satisfacción de los agricultores en el trabajo. Los materiales y método adoptados con este propósito corresponden a datos primarios obtenidos de un cuestionario y procesados mediante la metodología de los Mínimos Cuadrados Parciales-Ecuaciones Estructurales. Los resultados han revelado que la participación de los agricultores en alianzas colaborativas los ayudan a lograr metas económicas como reducir costos y obtener mejores precios para su producción. Esto, a su vez, afecta positivamente su satisfacción en el trabajo en términos de disfrutar el estilo de vida en el campo. Se concluye, entonces, que la colaboración y la satisfacción en el trabajo de los agricultores no solo están ligadas a una dimensión social sino que también a una dimensión económica. Ambas dimensiones se complementan y ofrecen posibles nuevas estrategias para las autoridades.

Palabras clave: desarrollo sostenible, sostenibilidad social, colaboración, satisfacción en el trabajo.

\footnotetext{
1 Universidad Diego Portales, Instituto de Ciencias Básicas, Facultad de Ingeniería, Santiago, Chile.

2 Harper Adams University, Department of Land, Farm and Agribusiness Management. Newport, Shropshire, United Kingdom.

3 Universidad Diego Portales, Facultad de Ingeniería, Santiago, Chile.

* Corresponding author: dmay@ harper-adams.ac.uk
}

Fecha de Recepción: 2 Octubre, 2016.

Fecha de Aceptación: 27 Noviembre, 2016.

DOI: $10.4067 / \mathrm{S} 0718-34292016005000040$. 


\section{Introduction}

The issue of sustainable development has attracted the attention of researchers for a long time. Given its plural nature, more than a hundred definitions of this term have been proposed in the literature, implying that no definition is conclusive (Frantzeskaki, 2012). According to Barkemeyer et al. (2014, p. 15), this concept is defined in the Brundtland Report as "development that meets the needs of the present without compromising the ability of future generations to meet their own needs". These researchers explain that this definition reconciles three key dimensions, namely: environmental sustainability; economic development and social sustainability.

In spite of the relevance of social sustainability for sustainable development, policymakers have traditionally shown a tendency to put more weight on environmental sustainability and economic development (Shreck et al., 2006; Hutchins and Sutherland, 2008; Wu et al., 2016). This is clearly identified in the rural sector. For example, in Europe reforms of the CAP (e.g. CAP reform of 1992, Agenda 2000 and the 2003 CAP reform) have incorporated the issue of rural development. Nonetheless, the main emphasis has been placed on achieving environmental standards and stabilizing farmers' income. This tendency is also observed in the political instruments introduced by the new CAP reform. For example, the Basic Payment Scheme (BPS) was introduced mainly to support farmers' income and includes new greening rules that farmers must follow in order to receive a greening payment that will be worth about $30 \%$ of the total payment. These rules were introduced with the purpose of strengthening the environmental sustainability of agriculture. Farmers who claim BPS also have to meet cross compliance rules (i.e. Standards of Good Agricultural and Environmental Condition, and Statutory Management Requirements) which correspond to a minimum set of requirements to help protect the environment, improve food safety and animal welfare (Finco et al., 2015).

The introduction of environmental objectives into the rural policy agenda is without doubt an extremely important policy initiative. Nonetheless, it is argued that these objectives may not be achieved without strengthening social sustainability. For example, Marshall et al. (2014) argue that because farming is a way of life and a social activity, social aspects of farming can affect farmers' decision-making, and therefore their incentives to be involved in sustainable development, particularly when they are less resilient. Efforts have been made to address the social side of sustainable development, leading to a number of alternative views. They include the relevance of maintaining the cultural and social system of interactions with ecosystems, ways in which society seen as a dynamic system may be induced to adapt in a sustainable manner, social participation to maintain social equity and social cohesion, and social and human capital indicators to measure social sustainability such as public services, nutrition, sanitation, living conditions, educational system, infrastructure and safety of the workplace (see for instance Dyllick, 2002; Hutchins et al., 2008; Frantzeskaki, 2012).

It is clear that all these aspects of social sustainability are relevant to facilitate sustainable development. However, there are other equally relevant social aspects that have received little attention, one of them being satisfaction at work. In this regard, it is interesting to note that the issue of lack of satisfaction at work has normally been linked to wage inequities (see for example Hutchins et al., 2008). For example, some researchers argue that the observed rural-urban migration phenomenon in different countries is explained by wage differential between rural and urban areas (Arzaghi and Rupasingha, 2013). Available evidence, however, has revealed that migration is not only explained by economic considerations, but also by socio-psychological factors such as socialization, secure life and the pull effect of friends and relatives (Usman et al., 2010). With respect to this point, Dyllick (2002) explains that when disaffection reaches a certain point, firms cannot undo this by simply offering higher wages or other financial benefits. Likewise, Bhatti and Dixon (2003) point out that it is a little unrealistic to expect people to care about global warming or species extinction when they are cold, hungry, seeking work or feel unsafe in their own home.

According to Mines (2003), non-economic factors that may cause farmers' lack of satisfaction at work are a mental health problem. This researcher argues that high levels of stress, anxiety and depression within farm worker communities are associated with the social isolation and insecure living and working conditions common in this population. On one hand, social isolation can lead to a sense of 
loneliness and lack of recognition from family or friends (Kallstrom and Ljung, 2005). On the other hand, insecure living and working conditions are related to the fact that agriculture is one of the most dangerous occupations because of the high risks associated with accidents and exposure to toxic substances, among others (Shreck et al., 2006).

Empirical studies have indeed confirmed farmers' concerns in relation to social aspects that affect satisfaction at work, such as the improvement of their quality of life, both personal and familiar, through the improvement of working conditions (Gafsi et al., 2006). In spite of this evidence, the same pattern identified in the general topic of sustainable development is found in the agricultural sector. That is, sustainable agriculture has focused mainly on economic and environmental considerations, and social aspects are addressed mainly in terms of physical living conditions and social justice (Van Calker et al., 2005).

A possible way to achieve social sustainability in terms of work satisfaction is farmer participation in collaborative initiatives (Kallstrom and Ljung, 2005). This is because collaboration allows farmers to improve social conditions (e.g. improving the level of social recognition, reducing the farmers' perception of loneliness and isolation, increasing participation in decision-making, network-building, positive feedback and better relationships with colleagues). In addition, because collaboration is a sort of social network (Kallstrom and Ljung, 2005), it can provide access to information social welfare and better working conditions (Hoang et al., 2006).

One of the key aspects of the study of Kallstrom and Ljung (2005) is that collaboration is seen by these researchers as a social activity that generates positive social externalities. The current article extends the work by Kallstrom and Ljung by exploring whether collaboration seen as an economic activity can also favor satisfaction at work. In this complementary view, collaboration can help farmers to achieve economic targets such as reducing input costs, influencing sale prices and strengthening farmers' ability to bargain collectively. This is because collaboration can help farmers to strive for favorable legislation and to countervail market power exercised by retailers (Valentinov, 2005; Shreck et al., 2006). It is argued in this article that the farmers' ability to achieve economic targets can positively affect satisfaction at work.

The aim of this study is, therefore, to investigate the role of farmers' collaboration as a tool to achieve economic targets that have the potential to favor satisfaction at work. For this purpose, the Partial Least Squares-Structural Equation Methodology was applied to a sample of ex-sugar beet farmers located in the West Midlands region of the UK.

\section{Material and Methods}

\section{Theoretical conceptual model}

The aim of this subsection is to introduce a theoretical model with the purpose of identifying specific channels by which satisfaction at work in rural areas may be improved when farmers participate in collaborative initiatives formed with the purpose of achieving economic targets. The economic dimension considered in this study refers to the ability of farmers to influence some economic variables. This ability is of course associated with the nature of collaboration. For example, large collaborative arrangements (e.g. market cooperatives) allow farmers to increase negotiating power, helping them to obtain better prices for their products, countervail power imbalance in the supply chain and gain access to certain markets (Valentinov, 2005; May and Tate, 2011). In contrast, small collaborative arrangements (e.g. farm supply cooperatives) allow farmers to reduce costs and risk by means of sharing resources, purchasing in volume, reducing information asymmetries, minimizing transaction and transport costs and coordinating business strategies (Gerichhausen et al., 2009; May and Tate, 2011; May, 2012). The proposed model captures these dimensions; it is presented in Figure 1.

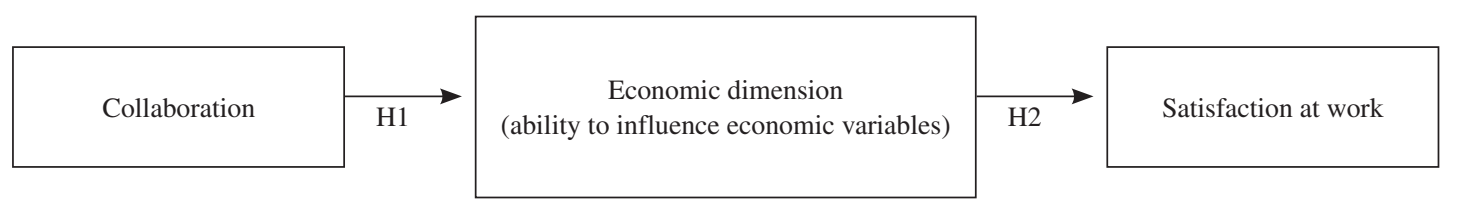

Figure 1. Model of satisfaction at work. 
In considering this model, two hypotheses were tested using the Structural Equations PLS method (see the next section). These hypotheses correspond to relationships represented as arrows in Figure 1. They link theoretical influences of certain constructs over others. These hypotheses are:

H1: The factor collaboration directly and positively influences the factor economic dimension.

$\mathrm{H} 2$ : The factor economic dimension directly and positively influences the factor satisfaction at work.

\section{Sample}

In order to collect relevant data to test the hypotheses outlined above, a sample of ex-sugar beet farmers in the West Midlands region of the UK was utilized. The reason for using this sample is because these farmers were strongly affected by the closure of the Allscott Sugar Factory in response to the Sugar Regime Reform implemented in 2006. As a result of this reform, the ex-sugar beet farmers had to adjust by adopting different strategies and crops (see May, 2012). Given the turbulent business environment suffered by these farmers, these individuals were expected to face a high degree of dissatisfaction at work in the transition. This makes this case study a useful case to test the link between collaboration and satisfaction at work.

According to the statistics of the Department for Environment, Food and Rural Affairs, the total number of sugar beet farmers in the target area in 2005 (i.e. before the Sugar Regime Reform) was 592. Of these, 49 were sampled, corresponding to 8.1 per cent of this population. Farmers in the sample were asked to answer a questionnaire in 2008. The data collection method was based on a combination of cluster, stratified, and snowball sampling techniques. These sampling methods were chosen because a list of sugar beet farmers was not available in the public domain.

The sample cluster was selected by choosing the most relevant counties of the West Midlands region in terms of the number of sugar beet farmers, namely Shropshire, Worcestershire, Herefordshire, Staffordshire and surrounding areas (accounting for $48 \%, 15 \%, 14 \%, 12 \%$, and $11 \%$ of the total sugar beet farm holdings in 2005, respectively). The sample considered relatively similar proportions for these counties in terms of the number of farmers that participated in the investigation (accounting for $46 \%, 15 \%, 13 \%, 15 \%$, and $13 \%$, respectively).

The sample stratification was made considering the size of the farm in terms of number of hectares. It was not possible to find official statistics for this variable. Nonetheless, a criterion was established based on the opinions of the 10 farmers that formed the pilot sample. The precaution was taken to include a balanced number of farmers in the classes defined by this measure.

The snowball technique was developed separately in each county. As a result, it was possible to find a number of sugar beet farmers consistent with the sample cluster strategy defined above. Given the difficulty in gathering data from primary sources and the small population of sugar beet farmers, the sample used in this study can be considered appropriate in this context.

\section{Questionnaire}

A questionnaire was used to collect the data that were needed to test the hypotheses described above. A five-point Likert scale was used to capture the value that farmers attributed to the statements included in the questionnaire that were considered as potential measures for the factors collaboration and economic dimension (see Appendix A). Some of these statements were adapted from Bergevoet et al. (2004), and others were introduced by the authors of this study.

The reason for adopting these statements is because there is no standard definition of satisfaction at work and economic dimension. In order to overcome this problem, it was found useful to consider a number of potential measures for these concepts/categories. Relevant and significant measures for each category were identified and grouped as factors by the Structural Equations PLS methodology.

In relation to collaboration, farmers were asked to use a five-point Likert scale to give their opinion on the economic variables that can be influenced when being involved in collaboration.

\section{Partial Least Squares-Structural Equation Methodology (PLS-SEM)}

The data obtained from the questionnaire were used to adjust the model of satisfaction at work by means of the PLS-SEM methodology. 
The general structural equations model combines the use of observable and latent variables. The structure considers two models referred to as the measurement model and structural model. The measurement model specifies the relationship between the observable variables and the underlying ones. In contrast, the structural model describes only the relationships between latent variables or constructs. Hair et al. (2013) defines the structural equations models as second generation multivariate analysis, whose purpose is to relate data and theory where a priori knowledge is incorporated into an empirical analysis.

There are two approaches to estimate the parameters of a Structural Equation Methodology (SEM), the covariance-based approach (CB-SEM) and the variance-based approach (PLS_SEM). The covariance-based approach "attempts to minimize the difference between the sample covariances and those predicted by the theoretical model. Therefore, the parameter estimation process attempts to reproduce the covariance matrix of the observed measures" (Chin and Newsted, 1999, p. 309). The aim of the PLS method of structural equations is to predict the dependent variables of the model by maximizing its explained variance $\left(\mathrm{R}^{2}\right)$, and estimating the parameters by minimizing the residual variances of the endogenous variances (Hair, 2013). The objectives of the two methods and the optimization algorism employed in the estimation of parameters are different.

The advantage of the PLS-SEM method is that it does not require normality in the data distribution and can also be used in small samples. This is in contrast to the related CB-SEM model which requires normality and large samples (Tenenhaus et al., 2005).
The PLS (Partial Least Squares) methodology has gained greater recognition in different academic areas such as information management systems, electronic commerce, marketing and agriculture. It was applied in the current study with the purpose of verifying the validity and reliability of both the measurement and the structural models, by quantifying the interrelations between the constructs and their effects on satisfaction at work.

\section{Results}

The objective of this section is to report the results of this investigation. They are presented in three steps, namely: results from the adjustment of the measurement model; results from the adjustment of the structural model and the descriptive results of the final model.

\section{Results from the adjustment of the measurement model}

The measurement model presented in Figure 2 describes how each latent variable is explained by the manifest variables. This model shows good psychometric properties, implying that the estimation of the latent variables is valid. The variables and factors that were significant are summarized in Table 1.

Methodological aspects that need to be verified are the compliance of determined criteria of validity and reliability of the measurement model. The individual reliability of the item as well as the composed reliability, the convergent validation and the discriminant validation meet the required parameters.

In particular, it can be seen in Table 2 that the individual reliability of each item is satisfied, with



Figure 2: Measurement model. 
Table 1. Relevant variables and factors.

\begin{tabular}{cl}
\hline Variables & \multicolumn{1}{c}{ Satisfaction at work factor } \\
\hline SW8 & Farming is still fun and satisfying \\
SW5 & $\begin{array}{l}\text { Preference for a healthy, outdoor, farming life } \\
\text { SW6 }\end{array}$ \\
I enjoy having a purpose and value hard work \\
\hline Variables & \multicolumn{1}{c}{ Economic dimension factor } \\
\hline ED6 & I can further lower the cost of price of my production \\
ED7 & $\begin{array}{l}\text { Before I take important decisions I thoroughly } \\
\text { inform myself }\end{array}$ \\
ED9 & I can increase the sales-price of my production \\
\hline Variables & \multicolumn{1}{c}{ Collaboration factor } \\
\hline CO1 & Collaborative alliances to access difficult markets \\
CO2 & Collaborative alliances to reduce market risk \\
CO3 & Collaborative alliances to increase negotiation power \\
CO4 & Collaborative alliances to reduce costs \\
\hline
\end{tabular}

Table 2. Indicators of the model.

\begin{tabular}{ccccc}
\hline \multicolumn{1}{c}{ Construct } & Indicator & Loading & AVE & IFC \\
\hline \multirow{4}{*}{ Economic dimension } & ED6 & 0.735 & & \\
& ED7 & 0.797 & 0.544 & 0.780 \\
& ED9 & 0.675 & & \\
\hline \multirow{4}{*}{ Collaboration } & CO1 & 0.924 & & \\
& CO2 & 0.900 & 0.705 & 0.902 \\
& CO3 & 0.927 & & \\
\hline \multirow{5}{*}{ Satisfaction at work } & CO4 & 0.633 & & \\
& SW8 & 0.803 & & \\
& SW5 & 0.767 & 0.644 & 0.844 \\
& SW6 & 0.836 & & \\
\hline
\end{tabular}

$\lambda$ values greater than 0.7 . Values equal to or greater than 0.707 imply that about $50 \%$ of the observed variance $\left(\lambda^{2}\right)$ is shared by the construct (Cepeda and Roldán, 2004). In addition, the index of composed reliability (IFC) of all the constructs takes values greater than 0.7 as required. This index measures the internal consistency of the indicators that compose each construct (i.e. the observable variables measure the latent variables).

The extracted mean variance (AVE) was greater than the minimum required value of 0.5 , meaning that the convergence validity is satisfied. This means that the construct shares more than the $50 \%$ of its variance with its indicators (Hair et al., 2013; Tenenhaus et al., 2005). Its function is to evaluate whether the set of items that measure the construct are indeed measuring this construct and not another one.

With respect to discriminant validity, the construct shared more variance with its indicators than with the rest of the constructs in all cases (Cepeda and Roldan, 2004).

\section{Results from the adjustment of the structural model}

Once the validity and reliability of the measurement model are verified, an evaluation of the structural model needs to be carried out. This model captures the hypothetical causality relationships between the constructs. In order to determine these relationships, the statistical significance of the parameters of the relationship between the constructs has to be reviewed. For this purpose, an equivalent to Student's t-test was estimated using a re-sampling technique (i.e. bootstrapping). Figure 3 shows the structural model and Table 3 presents the $t$ values. These values reveal that the latent regression coefficients are highly significant. The path coefficients or standardized weights of the regression ( $(B)$ measure the strength of the relationship between the constructs or the hypotheses of the causal relationship proposed. For this index desirable values must be greater than 0.3 .

In order to evaluate the predictive relevance of the model, the Blindfolding procedure by means of the $\mathrm{Q}^{2}$ index was adopted (Tenenhaus et al. 2005). In this case part of the data for a construct is omitted during the parameter estimation with the purpose of estimating the omitted data using the parameter estimated in the first step of the process (Chin and Newsted, 1999). The results obtained from this technique were all positive, indicating that the predictive relevance of the model is satisfied.

The explained variance by means of the index indicates that the value of the variance of the endogenous construct that is explained by the model must be greater than 0.1 . This requirement was satisfied for both endogenous constructs (see Table 4).

In summary, the model has good psychometric properties and they validate the estimation of latent variables. The global adjustment of the model is acceptable ith a positive predictive relevance $\mathrm{Q}^{2}$ for all the constructs. 




Figure 3. Structural model, Student t-test, bootstrapping technique.

Table 3. Bootstrapping results.

\begin{tabular}{lcc}
\hline \multicolumn{1}{c}{ Relationship } & Beta & t value \\
\hline Collaboration -> Economic dimension & 0.363 & 4.187 \\
Economic dimension -> Satisfaction at work & 0.370 & 3.234 \\
\hline
\end{tabular}

\section{Discussion}

The results obtained in the current study support the two hypotheses that relate collaboration with satisfaction at work. That is, the formation of different forms of collaboration in terms of their targets (i.e. to access difficult markets, reduce market risk, increase negotiation power and reduce costs) helps farmers to achieve economic goals such as reducing production costs, obtaining relevant information and increasing sale prices. While this is consistent with the research on collaborative alliances developed by researchers working in business and economic sciences, what is new in this study is that these economic goals exercise a positive effect on farmers' satisfaction at work that is captured by the statements "farming is still fun and satisfying", "preference for a healthy, outdoor, farming life", and "I enjoy having a purpose and value hard work".

The main implication of this finding is that collaboration not only has to be seen as a social aspect of the rural world that helps farmers to improve social conditions (e.g. improving social recognition, reducing farmers' perception of loneliness and
Table 4: Results of $R^{2}$ and $Q^{2}$.

\begin{tabular}{lcc}
\hline Endogenous constructs & $R^{2}$ & $Q^{2}$ \\
\hline Economic dimension & 0.1343 & 0.0741 \\
Satisfaction at work & 0.1368 & 0.0617 \\
\hline
\end{tabular}

isolation and better relationships with colleagues, among others) but also as a way to improve economic performance, because it contributes to achieving satisfaction at work. In considering this duality of collaboration, a more suitable model of farmers' satisfaction at work which complements the traditional view of collaboration that considers a social dimension as a mediating factor between collaboration and satisfaction at work is the one presented in Figure 4.

The proposed model offers some interesting possibilities to policymakers. As explained in the literature review, sustainable development includes three main dimensions, namely: economic development, environmental sustainability and social sustainability. Among these dimensions, more emphasis has been placed on economic development and environmental sustainability. It is argued that achieving environmental goals may be difficult when the social sustainability dimension is neglected, because it is related to satisfaction at work. That is, farmers who are not satisfied in their working place may not be willing to engage in environmental initiatives. Considering the model presented in Figure 4, a way to induce 


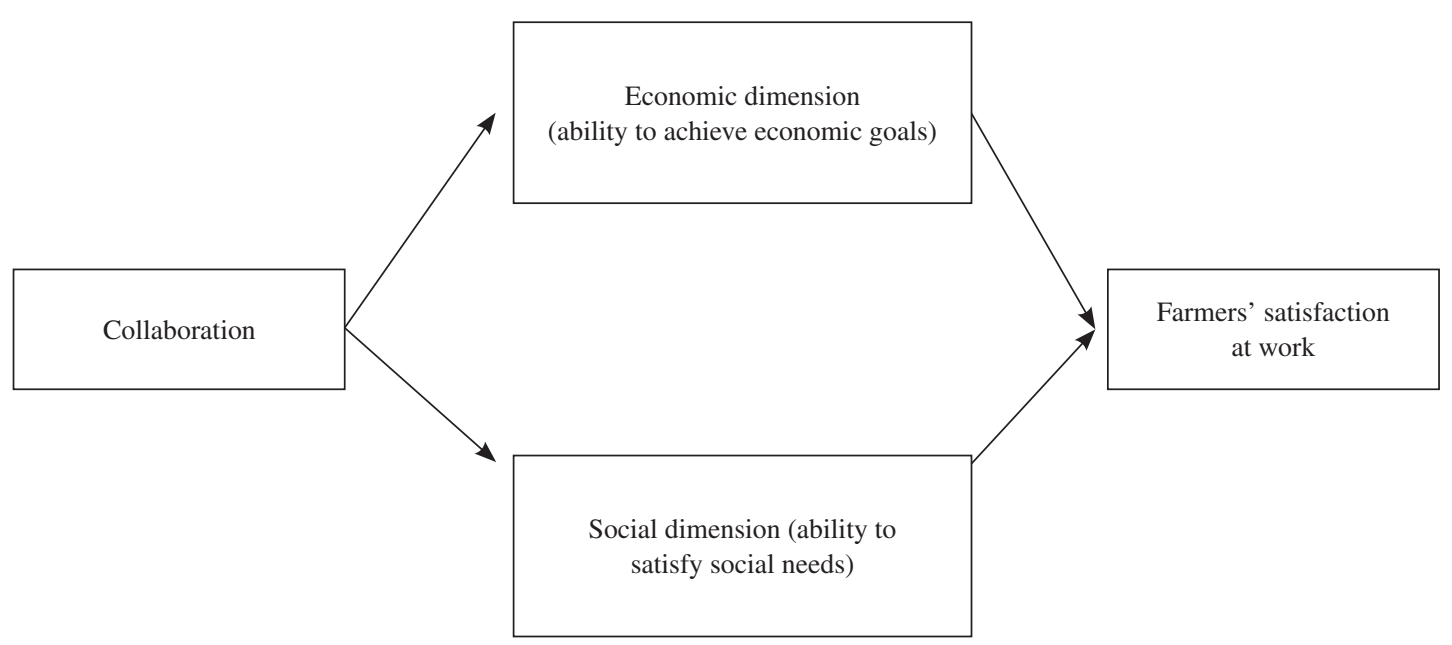

Figure 4. Extended model of farmers' satisfaction at work.

farmers to adopt environmental practices is by creating favorable working conditions; this can be done by developing local policies that promote the formation of collaborative alliances. In this case, these policies can be designed to address the dual effect of collaboration on satisfaction at work. That is, to help farmers to satisfy social needs as well as achieve economic targets. Because this dual effect is complementary, it may contribute to create important synergy in terms of farmers' satisfaction at work.

Different strategies may be adopted to facilitate this synergy. For example, communal meetings organized by local policymakers may assist in bringing farmers together with the purpose of creating an appropriate social environment in order to strengthen the social dimension of collaboration and satisfaction at work. This can be accompanied by invited experts to explain the economic benefits of forming collaborative alliances between farmers. Another alternative is to invite farmers to local colleges or universities to explain the benefits of generating social and economic synergies through collaboration. In this regard, it is argued in this article that funded pilot projects for this type of activity may be promoted and encouraged by relevant actors such as ministries of agriculture in different countries.

\section{Conclusions}

Results from research in rural sociology have revealed that collaboration positively affects farmers' satisfaction at work because it improves social conditions related to social recognition, farmers' perception of loneliness and isolation, participation in decision-making, network-building, positive feedback and better relationships with colleagues. The current study extends this research by adding another channel by which collaboration in the form of alliances improves satisfaction at work. In this channel, these alliances help farmers to achieve economic goals such as cost reduction, sale price increase and the acquisition of relevant market information. These economic goals, in turn, positively affect satisfaction at work in terms of enjoyment in the farm, life style and enjoyment of having a purpose and the value of hard work.

This alternative channel between collaboration and farmers' satisfaction at work not only complements the traditional view of collaboration as a social dimension in rural areas, but also offers scope for alternative and complementary policy strategies which can create synergies that can potentially reinforce satisfaction at work. This may be achieved by combining the social and economic dimensions of collaboration in order to strength its impact on satisfaction in the working place. Moreover, this has the potential to induce farmers to adopt other initiatives such as environmental programs. The reason is because according to some researchers the adoption of these programs depends on the level of farmers' satisfaction. Specific policy formulas for this purpose are left for future research. 


\section{Appendix A: Statements used in the questionnaire}

\section{Statements Related to Satisfaction at Work}

SW1) Enjoy my work

SW2) Working with other members of the family

SW3) Have sufficient time for leisure

SW4) Enjoyment of work tasks

SW5) Preference for a healthy, outdoor, farming life

SW6) I enjoy having a purpose and value hard work

SW7) Have independence and freedom from supervision

SW8) Farming is still fun and satisfying

SW9) I would seriously advise young people not to become a farmer

SW10) Administrative obligations consume a lot of time on my farm

\section{Statements Related to the Economic Dimension}

ED1) Achieve an income as high as possible

ED2) Achieve low debts on my farm

ED3) Off-farm income is important for sustaining our farm

ED4) I use my equity capital as a risk buffer

ED5) I try to minimise contract work

ED6) I can further lower my production costs

ED7) Before I take important economic decisions I thoroughly inform myself

ED8) When I need a new loan, I always go to the same bank

ED9) I can increase the sales-price of my production

ED10) I like to try new things on my farm

\section{Statements Related to Collaboration}

CO1) Collaboration is useful to access difficult markets

$\mathrm{CO} 2)$ Collaboration is useful to reduce market risk

$\mathrm{CO} 3)$ Collaboration is useful to increase negotiation power

$\mathrm{CO} 4)$ Collaboration is useful to reduce production costs

\section{Literature Cited}

Arzaghi, M.; Rupasingha, A.

2013. Migration as a way to diversify: Evidence from Rural to Urban Migration in the U.S. Journal of Regional Science, 53 (4). 690-711.

Barkemeyer, R.; Holt, D.; Preuss, L. and Tsang, S. 2014. What happened to the development in 'sustainable development'? Sustainable Development, 22 (1): 15-32.

Bergevoet, R.H.M.; Ondersteijn, C.J.M.; Saatkamp, H.W.; van

Woerkum, C.M.J.; Huirne, R.B.M.

2004. Entrepreneurial behaviour of Dutch dairy farmers under a milk quota system: goals, objectives and attitudes. Agricultural Systems, 80 (1): 1-21.

Bhatti, M.; Dixon, A.

2003 Special focus: housing, environment and sustainability. Housing Studies, 18 (4): 501-504.
Cepeda, G.; Roldán, J.L. 2004. Aplicando en la práctica la técnica PLS. In: Congreso de la ACEDE. Murcia, España, pp. 74-78.

Chin, W.W.; Newsted, P.R.

1999. Structural equation modelling analysis with small samples using partial least squares. In R.H. Hoyle (Ed.), Statistical strategies for small sample research (pp. 307341). Thousand Oaks, CA: Sage.

Dyllick, T.; Hockerts, K.

2002. Beyond the business case for corporate sustainability. Business Strategy and the Environment. 11 (2): 130-141.

Finco, A.; Bentivoglio, D.; Meo, R.

2015. Old and new style of greening payments: economic and environmental implications for italian agriculture. I: XLIII Incontro di Studio del Ce.S.E.T. Firenze University Press. Verona, Italy, pp. 33-49. 
Frantzeskaki, N.; Loorbach, D.; Meadowcroft, J.

2012. Governing societal transitions to sustainability. International Journal of Sustainable Development, 15 (1/2): 19-36.

Gafsi, M.; Nguyen, G.; Legagneux, B.; Robin, P. 2006. Sustainability and multifunctionality in French farms: Analysis of the implementation of Territorial Farming Contracts. Agriculture and Human Values, 23 (4): 463-475.

Gerichhausen, M.; Berkhout, E.D.; Hamers, J.H.M.; Manyong, V.M. 2009. A quantitative framework to analyse cooperation between rural households. Agricultural Systems, 101 (3): 173-185.

Hair, J.F.; Hult, G.T.M.; Ringle, C.M. and Sarstedt, M. 2013. A Primer on Partial Least Squares Structural Equation Modeling (PLS-SEM). Sage. New York, 384.

Hoang, L.A.; Castella, J.C.; Novosad, P.

2006. Social networks and information access: Implications for agricultural extension in a rice farming community in northern Vietnam. Agriculture and Human Values, 23 (4): 513-527.

Hutchins, M.J.; Sutherland, J.W.

2008. An exploration of measures of social sustainability and their application to supply chain decisions. Journal of Cleaner Production, 16 (15): 1688-1698.

Kallstrom, H.N.; Ljung, M.

2005. Social Sustainability and Collaborative Learning. Ambio, 34 (4-5): 376-382.

Marshall, N.A.; Stokes, C.J.; Webb, N.P.; Marshall, P.A.;

Lankester, A.J.

2014. Social vulnerability to climate change in primary producers: A typology approach. Agriculture, Ecosystems and Environment, 186: 86-93.

May, D.E.

2012. Non-economic drivers influencing farmers' incentives to cooperate: do they remain robust through policy changes? Journal of Rural Cooperation, 40 (2): 217-238.
May, D.E.; Tate, G.

2011 Exploring economic and social-psychological factors in explaining farmers' willingness to participate in cooperative alliances. International Journal of Strategic Business Alliances, 2 (4): 329-346.

Mines, R.

2003. Farmworker health in a binational context. Challenges in Agricultural Health and Safety Conference, September 7-9, San Francisco, California.

Shreck, A.; Getz, C.; Feenstra, G.

2006. Social sustainability, farm labor, and organic agriculture: Findings from an exploratory analysis. Agriculture and Human Values, 23 (4): 439-449.

Tenenhaus, M.; Esposito Vinzi, V.; Chatelin, Y.; Lauro, C. 2005. PLS path modeling. Computational Statistics and Data Analysis, 48: 159-205.

Usman, M.; Naeem, M.; Khan, Z.

2010. Socio-economic Determinants of Migration of People from Rural Areas to Urban Areas of District Peshawar. Journal of Managerial Sciences, 4 (2): 138-150.

Valentinov, V.

2005. The organizational nature of agricultural cooperatives: a perspective from the farm problem theory. Journal of Rural Cooperation, 33 (2): 139-151.

Van Calker, K.J.; Berentsen, P.B.M.; Giesen, G.W.J.; Huirne, R.B.M.

2005. Identifying and ranking attributes that determine sustainability in Dutch dairy farming, Agriculture and Human Values, 22 (1): 53-63.

Wu, S.R.; Fan, P.; Chen, J.

2016. Incorporating Culture Into Sustainable Development: A Cultural Sustainability Index Framework for Green Buildings. Sustainable Development, 24 (1): 64-76. 